\title{
A személy- és vagyonörök objektumspecifikus fejlesztési terve (IDPS) MOP-kiterjesztéssel
}

\section{SZABÓ Anikó ${ }^{1 \oplus}$ - KOVÁCS Éva ${ }^{2 \oplus}$}

\begin{abstract}
A személy- és vagyonőrök szerepe a magánbiztonságban, közös, szubjektív biztonságérzetünk megteremtésében és fenntartásában vitathatatlan. A személy-és vagyonőrök formális képzését követően is szükség van ismereteik folyamatos bővitésére és frissítésére. Ennek irányulnia kell a jogi környezet változásának nyomon követésére, a munkavégzésük során használt technikai újdonságok használatára, a munka- és tüzvédelmi tevékenységek és eszközök ismeretére és alkalmazására. A munkakörre jellemző fluktuáció ugyanakkor megnehezíti, sokszor ellehetetleníti azt az elengedhetetlenül szükséges tudástranszfert, amely egyes objektumok, speciális létesítmények, önálló munkavégzési helyszínek és munkakörök ellátásához szükséges lenne. Erre az igényre válaszul fogalmazta meg a szerző Szabó Anikó a Személy-és Vagyonörök Objektumspecifikus Fejlesztési Tervét (Internal Development Plan for Security Guards - IDPS), amely rugalmas, modulrendszerü belső képzési megoldást kínál a szakma képviselőinek a problémára. A képzési terv integráltan tartalmazza kommunikációs moduljának részeként a Kovács Éva által alkalmazott Feladatorientált Felkészítés (Mission Oriented Preparation - MOP) módszereit is.
\end{abstract}

Kulcsszavak: személy-és vagyonőr, fejlesztési terv, Feladatorientált Felkészítés, magánbiztonság, objektumvédelem, biztonságtechnikai szaknyelv

\section{Az IDPS és MOP létjogosultsága}

A hazai magánbiztonsági ágazatban tevékenykedő szakemberek alapvető célja, hogy az a személy, aki személy- és vagyonőrként kíván munkát vállalni, szakmailag folyamatosan felkészült legyen. Ennek érdekében - első lépésként - a szakmai képzés minőségi megvalósításán túl az őrszolgálat tagjainak időszakosan a szakmai kamara

Szabó Anikó, okleveles biztonságtechnikai mérnök, személybiztonsági szakértő, Óbudai Egyetem Biztonságtudományi Doktori Iskola, doktori hallgató.

Anikó Szabó, Certified Security Technology Engineer, Personnel Protection Facility Security Expert, Óbuda University, Doctoral School on Safety and Security Sciences, PhD student. E-mail: aniko.szabo.bdi@gmail.com

2 Kovács Éva, Nemzeti Közszolgálati Egyetem Rendészettudományi Kar Idegennyelvi és Szaknyelvi Lektorátus, angol nyelvtanár, Óbudai Egyetem Biztonságtudományi Doktori Iskola, doktori hallgató.

Éva Kovács, University of Public Service Faculty of Law Enforcement Department of Foreign Languages for Specific Purposes, Teacher of English for Specific Purposes, Óbuda University Doctoral School on Safety and Security Sciences, PhD student. E-mail: KovacsE@uni-nke.hu 
által szervezett képzésen is részt kell vennie, ha tevékenységét hosszú távon folytatni kívánja. Ez a folyamat jelentős lépés annak érdekében, hogy az esetlegesen elavult, megkopott ismereteket közös, egységes szintre hozza, a változásokat követve kapjanak az őrök egységes szemléletet, ismereteket.

Ugyanakkor, ahogy például egy rendezvényhelyszínen az adott koncert előtt eligazítást tartanak az őröknek az esemény, a vendégkör jellemzőiről, a kapcsolódó feladatokról, ahogy bejárást tartanak az épületben, sajátosságairól, átbeszélik az esemény kapcsán szükséges teendőket, úgy a folyamatos, 24 órás őrzési tevékenység is megkívánná ezt a fajta időszakos figyelmet az őrszolgálat tudásának felfrissítése érdekében.

Tapasztalat szerint azonban a tudásnak ez a fajta szinten tartása általában nem történik meg. Bár az állománygyưlések keretében létezik évente ismétlődő belső oktatás a munkáltató részéről - érthető módon -, az őrök alkalmazási formájára és annak körülményeire hivatkozva ennél több nem történik. Emiatt az alkalmazott biztonsági őrök elvárt elméleti és gyakorlati ismeretein túl nem jelenik meg az ismeretek napi üzemeltetési feladatokhoz, az objektum jellemzőihez igazítása. Ezen ismereteket a régebb óta az adott telephelyen szolgálatot ellátó őrök szájhagyomány útján, feladathoz igazodva adják át az újonnan érkezőknek, időnként tudtuk nélkül, vagy a megszokásra hagyatkozva hibásan, hiányosan, és semmiképpen sem szervezetten, sem az ismeretanyag, sem a módszer tekintetében. Az ismeretek megértése, rögzülése, alkalmazásának ellenőrzése pedig még inkább elmarad, legroszszabb esetben egy esemény során tett intézkedésből szűrhető le annak minősége. A bizonytalan vagy hibás eljárás pedig mind a megrendelő, mind a külső személyek, például vendégek, ügyfelek, beszállítók negatív tapasztalatait gazdagíthatja majd, a biztonsági koncepció végrehajtásának hatásfoka csökkenhet, de akár az esetleges visszaélés lehetőségére hívva fel az erre fogékony emberek figyelmét. Ezenkívül további problémaforrást jelent, ha az anyanyelv helyett más idegen nyelven, jellemzően angolul kell kommunikálni.

Annak érdekében, hogy a komplex vagyonvédelmi rendszerben az embert mint leggyengébb láncszemet, mint magas kockázati forrást optimalizáljuk, az őrszolgálat tagjainak oktatására rendszeresen figyelmet kell fordítani. Ennek érdekében készül a „Személy- és vagyonőrök objektumspecifikus fejlesztési terve”, a magyarországi foglalkoztatási viszonyokhoz igazodva, a személy- és vagyonőri képzésen alapulva. Jelen tanulmány célja a tervben foglalt szakmai tartalom és az angol nyelvi program bemutatása az objektum sajátos igényeire fókuszálva.

\section{Az IDPS felépítése}

A biztonsági szolgálat tagjainak szakmai felkészültsége jelentős mértékben hozzájárul a komplex védelem hatékonyságához, a magabiztos és szakszerú intézkedéshez, az objektumban tartózkodó személyek biztonságérzetéhez, a bekövetkező 
károk mértékének enyhítéséhez. ${ }^{3} \mathrm{Az}$ őrszolgálat folyamatos képzési igényét, a tudásuk fejlesztését az adott tevékenységre fókuszálva több hazai őrzés-védelemmel foglalkozó publikáció megemlíti. ${ }^{4}$ Nemzetközi források szintén gyakran utalnak a feladatspecifikus képzés fontosságára az általános, megalapozó ismeretek mellett. ${ }^{5}$ Ennek érdekében a mindennapi szakmai munkavégzéshez szorosan kapcsolódó, kézzelfogható és praktikus tudást kell kapniuk az objektumban szolgálatot ellátó vagyonőröknek egységesen, de mégis feladatspecifikusan a 2012. évi CXX. törvény és a 68/2012. (XII. 14.) BM rendelet céljával összhangban, a személy- és vagyonőri szakmai képzés vizsgakövetelményein alapulva. ${ }^{6}$ Ennek megvalósítása érdekében készül az IDPS, a személy- és vagyonőrök objektumspecifikus fejlesztési terve.

A szakmai képzés ad a leendő vagyonőrnek egy kezdeti, induló elméleti és gyakorlati ismeretanyagot, és az időszakos vizsgák, munkáltatói képzések frissítik ezt a tudást, azonban az elmélyítést és a munkakör speciális ismereteinek hozzákapcsolását csak a gyakorlatban lehet megvalósítani. Az IDPS célja, hogy a személy- és vagyonőr szakképesítéssel rendelkező objektumőrök szakmai felkészítését ezzel tegye teljessé, az objektumspecifikus belső képzésen keresztül a mindennapos gyakorlati ismerteken és szituációs gyakorlati képzésen keresztül valósághű körülményeket biztosítva frissítik, fejlesztik a tudásukat az őrök, ahol a megélt helyzetek, az abból levont következtetések mind-mind hozzákapcsolhatók az egyébként száraznak tűnő és esetenként levegőben lógó ismeretekhez. ${ }^{7} \mathrm{Az}$ objektumvédelmi szakember feladata, hogy a védett objektum egyéni igényeihez igazítsa a tervet, hozzátéve azokat a speciális ismereteket, feladatokat, amelyek az adott helyre jellemzők. Hiszen más feladatok keletkeznek egy kórházban, egy gyár telephelyén, egy kombinált struktúrával rendelkező objektumban, ahol hatósági jogkörű feladatokat látnak el, vagy ahol kritikus infrastruktúra védelmét kell ellátni, ahol a személy- és vagyonőrök mellett fegyveres biztonsági őrök is szolgálatot adnak.

Ezeknek a rendszeres belső képzéseknek jellemző motívuma, hogy a munkaidő terhére történnek, ${ }^{8}$ kihasználva a holtidőket. A terv képzési ciklusa egy év, heti kétórás oktatásokkal számolva, ahol a személyes oktatás és az e-learning-oktatás egy-egy órát foglal magában. Amennyiben csak a személyes oktatás valósítható

\footnotetext{
Zsákai Róbert - Muhoray Árpád: A pszichés viselkedések szerepe a katasztrófahelyzetekben. Szakmai Szemle, (2014), 3. 214-223.

4 Bodrácska Gyula: Vagyonvédelmi kockázatok az építőiparban különös tekintettel a lopások fajtáira, típusaira, anyagaira, segédanyagaira. Hadmérnök, 5. (2010), 1. 5-14; Berek Tamás - Bodrácska Gyula: Az élőerős őrzés az objektumvédelem építőipari ágazatában. Hadmérnök, 5. (2010), 4. 38-49; Lasz György: A legjobb gyakorlat: Fejlesztés és fejlődés. Hadmérnök, 6. (2011), 1. 59-72.

Glen Kitteringham: A development guide. Security Management, (2020), 7.

610323009 számú Személy- és vagyonőr megnevezésű szakképesítés megszerzésére irányuló szakmai képzéseket megalapozó programkövetelmény; 68/2012. (XII. 14.) BM rendelet a rendészeti feladatokat ellátó személyek, a segédfelügyelők, valamint a személy- és vagyonőrök képzéséről és vizsgáztatásáról; 2012. évi CXX. törvény az egyes rendészeti feladatokat ellátó személyek tevékenységéről, valamint egyes törvényeknek az iskolakerülés elleni fellépést biztosító módosításáról.

7 Berek Tamás: ABV (CBRN) analitikai laboratórium beléptetőrendszere a biztonságos üzemeltetés szolgálatában. Hadmérnök, 6. (2011), 2. 21-36.

8 Berek-Bodrácska (2010): i. m.
} 
meg, úgy az oktatás heti egy órában történik. A rugalmas átcsoportosítás megvalósíthatóságával is számolni kell, ezért az éves képzési tervben üres képzési napokat is fenn kell tartani, amennyiben egy adott nap képzése egy-egy váratlan feladat miatt meghiúsul. Az őrszolgálat tagjai rotációban vesznek részt, amellyel figyelembe lehet venni a távolléteket. A képzésbe bárhol be lehet kapcsolódni, így például az újonnan belépő őrök tudásszintjét rögtön el lehet kezdeni az objektum speciális ismereteivel bővíteni.

Az oktatás módszereit tekintve mind a személyes, mind az e-learning forma alkalmazható. A gyakorlati ismeretek átadásához, a közvetlen, téma szerinti kötetlen beszélgetéshez a személyes oktatás javasolt, míg az e-learning olyan témák feldolgozását segíti, amelyekben tananyag átolvasásáé a főszerep, ahol a feldolgozás videók, tesztek, feladatok segítségével történik. A visszamérés ugyancsak e módszereket használja az elektronikus forma előnyben részesítésével. Az e-learning bevezetése azonban tananyagfejlesztést is kíván e platformra, amely előzetes anyagi, tervezési ráfordítást igényel.

Helyszínét tekintve a szolgálatadás helyéhez közel tartandó egy különálló helyiségben, a napi forgalom zajától mentesítve. Ugyanakkor amennyiben intézkedni szükséges, az őrök ismét az alapvető feladatuk ellátására koncentrálnak, vagyis a képzési folyamatnak azonnal megszakíthatónak kell lennie, és az őröknek a lehető legrövidebb időn belül vissza kell tudni érni a szolgálati helyükre. Emiatt egy objektumon belüli képzésre kijelölt terem, amely a szolgálati helytől távol esik, természetesen szóba sem jöhet.

Az oktatásokat az objektum biztonsági szakterülete, a vezetője vagy az ő megbízottja tartja a vagyonvédelmi szolgáltató együttmúködésével. A szakmai tartalom az éves, szolgáltató által kötelezően tartott oktatásokat is figyelembe veszi. Ugyanis a vagyonvédelmi szolgáltató által felhalmozott ismeretek és tapasztalatok ugyancsak hozzájárulnak az oktatás hatékonyságához. Ez alapján olyan oktatói kört kell kialakítani, akik stabilan részt tudnak vállalni. Ahhoz, hogy az egyes témák szerinti tartalmakat az előadók felelősségteljesen át tudják adni, nekik is szükséges képezni magukat, a tudásukat felfrissíteni, csiszolni. Tapasztalatom szerint a biztonsági szakemberek között jelentős tudás-és tapasztalatbeli különbségek mutatkoznak, így a képzési program hatékonyságának érdekében rendszeres és önálló erőfeszítéseket kell tenniük a tudásuk bővítésére. Emellett az átadott ismeretek elmélyítésére, ellenőrzésére is időt kell fordítani a biztonsági szolgálat egyéni jellemzőihez igazodva.

Az IDPS modulrendszerű, nyolc modulból épül fel, az egyes modulok alá kerültek azok a tantárgyak, amelyek tartalmi elemei az arányosság, célszerúség elvét követve a leginkább illeszkedtek az adott modul tartalmához. Mivel azonban a tantárgyak tartalmi elemei nem önálló egységként épülnek fel, hanem minden esetben egymáshoz kapcsolódnak, ezért az egyes tantárgyak más modulokhoz is kapcsolhatók, átcsoportosíthatók. A modulok tantárgyak szerinti eloszlását, rövid leírását a következőkben ismertetem. 


\section{Az IDPS szakmai tartalma}

\section{Jogi ismeretek modul}

Az etikai elvárások tantárgy keretében a biztonsági szolgálat tagjainak ismerniük kell az etikus magatartás szabályait a magánéletükben is követve, hozzájárulva a szakma jó hírnevéhez..$^{9}$ Az etikai elvárások tantárgy keretében ehhez kapcsolódó kézzel fogható, a mindennapokban is alkalmazható példák mentén kell oktatni a vagyonőröket. A személy- és vagyonőrök szakmai követelménye támpontot ad az elvárt viselkedésmódokra, attitűdökre, amelynek kiegészítése lehet a rendőri hivatás etikai kódexe a rájuk vonatkoztatható részekkel. ${ }^{10}$

$\mathrm{Az}$ őrzött létesítmény üzemeltetésekor és az azt ért támadás, büncselekmény észlelésekor, rendkívüli esemény kapcsán az alapvető és szakmai tevékenységet szabályozó jogszabályok, a belső szabályzatok, az őrutasítás szerint kell az őrszolgálatnak eljárnia gyorsan és hatékonyan cselekedve, a legkisebb károkozás mellett. ${ }^{11}$

Az általános jogi ismeretek tantárgyhoz köthetően esetpéldákon keresztül szükséges a jogelméleti alapismeretek mellett időszakosan ismételni az alkotmányjogi és államigazgatási jogi ismeretek, a polgári jogi ismeretek, a büntetőjogi ismeretek és a büntetőeljárási jogi ismeretek vonatkozó részeit. ${ }^{12} \mathrm{~A}$ szakmai területet szabályozó jogi ismeretek tantárgy során pedig ismételni szükséges a vagyonvédelmi törvény és a végrehajtói rendelet, a fegyverhasználat előírásait, kiegészítve a modult egy harmadik tantárggyal, az egyéb a feladatvégzéshez köthető jogi ismereteket öszszefoglalva. ${ }^{13}$

\section{Munka-, tüz-, környezetvédelem modul}

A személy- és vagyonőri munkakör betöltésének alapfeltétele a munka-, tüz- és környezetvédelmi előírások ismerete, amelynek teljesítése a szolgáltató által tartott éves oktatás keretében történik az IDPS részeként. Ezen oktatás keretében nemcsak mint munkavállalók kapnak ismereteket, hanem mint a vagyonőri munkavégzéshez köthető feladatokhoz is, például túzeset miatti kiürítés teendői, balesetet követő helyszínbiztosítás.

9 Személy-, Vagyonvédelmi és Magánnyomozói Szakmai Kamara: Etikai szabályzat. 2016.

1010323009 számú Személy- és vagyonőr megnevezésű szakképesítés megszerzésére irányuló szakmai képzéseket megalapozó programkövetelmény; Rendőrség: A rendőri hivatás etikai kódexe.

11 Váradi Julianna: Általános és speciális jogszabályi elöirások, és etikai szabályok. NSZFI Személy-és vagyonvédelmi alapfeladatok. Nemzeti Szakképzési és Felnőttképzési Intézet, é. n. 1-6.

12 Guttengeber Ádám: Személy- és vagyonörök, biztonságtechnikai szakemberek tankönyve. I. fejezet. Budapest, Pro-Sec Kft., 2000.

13 2005. évi CXXXIII. törvény a személy- és vagyonvédelmi, valamint a magánnyomozói tevékenység szabályairól; 22/2006. (IV. 25.) BM rendelet a személy- és vagyonvédelmi, valamint a magánnyomozói tevékenység szabályairól szóló 2005. évi CXXXIII. törvény végrehajtásáról. 
A munkavédelem tantárgy szerint a vagyonőröknek tudniuk kell a munkavállalók jogairól és kötelezettségeiről, az egyes fogalmak jelentéséről, a közöttük lévő összefüggésekről. Például mi számít munkabalesetnek, mi üzemi balesetnek, mi a baleset és a kvázi baleset közötti különbség. Tudniuk kell, hogy milyen veszélyes anyagokkal találkozhatnak a munkavégzésük során, hogyan lehet a baleseteket megelőzni. Ha mégis bekövetkezett a baleset, milyen teendők merülnek fel, milyen elsősegélynyújtási feladatok keletkeznek, milyen technikákat kell alkalmazniuk, hogyan kell a baleset helyszínét biztosítaniuk.

A munkavédelem keretében az ergonómiai ismeretekről is szólni kell, hozzájárulva az egészséges munkavégzés biztosításához. Abban az esetben, ha a vagyonőröknek gépjármúhasználathoz köthető feladatuk is keletkezik, úgy a biztonságos közlekedésről is beszélni kell a baleset- és büntetésmentes közlekedés megvalósulása érdekében.

Tűzvédelem tantárgy keretében tisztában kell lenni az alapvető tűzmegelőzési feladatokkal, hogyan lehet a munkakörnyezet biztonságát fenntartani, hogyan lehet a tűzeseteket megelőzni, például dohányozni milyen szabályok betartása mellett lehet az objektumban. Amennyiben mégis tűz keletkezik, úgy tudni kell a környezetet a túz észleléséről tájékoztatni szóban, technikailag és segélyhívó számon keresztül. Tudni kell, hogy a segélyhívás esetén milyen tartalmi információkat kell megadni. Ismerni kell a tűzeseti teendőket és kommunikációt. Tisztában kell lenni a kiürítési terv alapján a kiürítés menetével, a felvonulási útvonalak biztosításával. Ismerni kell az objektum tűzoltási lehetőségeit, eszközeit, azok múködési mechanizmusát, annak érdekében, hogy a kezdeti stádiumban lévő tűz megfékezhető legyen. ${ }^{14}$

A környezetvédelem tantárgy során az őrök információt kapnak az irodai munkakörnyezet hatásairól, például a világítás, fütés szabályozásának hatásáról, a környezetvédelmi célokról, a környezeti hatás csökkentésének lehetőségeiről, a hulladékgyưjtés, és a szelektív hulladékgyújtés objektumon belüli megvalósítási folyamatáról.

\section{Objektumspecifikus ismeretek modul}

Az objektum jellemzői tantárgy keretében a vagyonőrt meg kell ismertetni az objektum felépítésével, főbb jellemzőivel, határoltságával, tagoltságával, az egyes területeken folyó tevékenységekkel. A vonatkozó mértékben ismernie kell a munkavégzéséhez kötődő belső szabályzatokat, ${ }^{15}$ mint például az őrutasítás, őrzésvédelmi szabályzat, biztonságtechnikai szabályzat, a tevékenységhez kapcsolódó szervezeti és múködési szabályzat, humánpolitikai szabályzat stb. Ismernie kell a biztonsági

\footnotetext{
4 Beregnyei József: Gyalogosok be/kiléptetése, ellenôrzése, csomagok átvizsgálása. Nemzeti Szakképzési és Felnőttképzési Intézet, é. n. (2), NSZFI Személy- és vagyonvédelmi alapfeladatok; Váradi Julianna: Általános és speciális jogszabályi előírások, normák, valamint az etikai, titokvédelmi szabályok. Munkaanyag. Nemzeti Szakképzési és Felnőttképzési Intézet, é. $\mathrm{n}$.

15 Szabó Anikó: A szabályzatok szerepe az objektumok őrzésvédelmében. Müszaki Katonai Közlöny, 27. (2017), 1. 2-15.
} 
szolgálat hierarchikus felépítését, a jelentési kötelezettségek folyamatát. Az alkalmazott technikai eszközök tantárgy keretében átismétlik, hogy mely technikai, híradástechnikai eszközök támogatásával végzik a szolgálatadást, ezek használati módját, szabályait, és ezeken kívül milyen irodatechnikai eszközök állnak rendelkezésükre, ezeket hogyan kell használni.

\section{Örzésvédelem modul}

A szolgálatadás tantárgy keretében az őrszolgálatnak tisztában kell lennie a vagyonőr általános kötelezettségeivel és jogaival, a szolgálatba átadás-átvétel folyamatával, az egyes dokumentumok kezelésével, a nyilvántartások vezetésével, kezelésével.

A járőrözés tantárgy során átismétlik a járőrtevékenység folyamatát mind épületen belül, mind kültéren, emellett fel kell ismerniük azokat a külső kockázati elemeket, amelyek az objektum biztonságát fenyegetik. ${ }^{16}$ Ismerniük, és megfelelően használniuk kell az objektumba telepített őrjárat-ellenőrző rendszert.

A beléptetés tantárgy során átismétlik a személyek beléptetési folyamatát, a ruházat ellenőrzését és vizsgálatát, a gépjármúvek beléptetését, illetve a csomagok, szállítmányok ellenőrzését.

$\mathrm{Az}$ objektumon belüli mozgás tantárgy a személyek és a gépjármúvek mozgásával kapcsolatos teendőket tárgyalja, a parkoláshoz köthető szabályokat frissíti fel. Ezenkívül az őrszolgálat tagjai ismétlik a kulcskezelés szabályait, a személyvédelem, a rendezvénybiztosítás, a szállítmánykísérés egyes feladatait.

\section{Biztonságtechnika modul}

Az objektum komplex védelmének egyik eleme a biztonságtechnikai rendszerek, elemek alkalmazása, amely a mechanikai védelmi elemek mellett az elektronikus biztonságtechnikai rendszereket is magában foglalja. A vagyonőröknek az objektumhoz köthető eszközöket stabilan kell tudni múködtetni, érteni az alapvető működési elvüket. Az eszközöket a lehetőségekhez, technikai korlátokhoz mérten, a kor kihívásaihoz, igényeihez igazodva használni szükséges. Ismerniük kell az objektumba telepített beléptető, behatolásjelző, videómegfigyelő, tűzjelző, -oltó, kulcskezelő, kaputelefon-rendszereket, ezek önállóan is működőképes alrendszereit, alapvető működési elveit, egymás közötti logikai kapcsolatait, illetve az integrált

\footnotetext{
6 Szabó, Anikó - Zoltán Rajnai: The review of the external risk factors during the operation training plan of the security guards. IEEE $15^{\text {th }}$ International Symposium on Intelligent Systems and Informatics (SISY). Szabadka, 2017; Sik Gotthilf: A védett objektumon belüli járốrszolgálat ellátása alapesetben. Nemzeti Szakképzési és Felnőttképzési Intézet, é. n.; Sik Gotthilf: A szolgálatra történő felkészülés, valamint a szolgálat átadása, átvétele, ennek jelentése. Nemzeti Szakképzési és Felnőttképzési Intézet, é. n.
} 
felületre beérkező jelzéseket, információkat. Tudni kell ezeket a rendszereket önállóan is múködtetni a felügyeleti rendszer meghibásodása esetén. ${ }^{17} \mathrm{~A}$ legmodernebb létesítmények múködtetése, valamint a felügyeleti tevékenységek ellátása kiemelten technológiaintenzív jellege miatt elképzelhetetlen a feladatra és eszközök múködtetésére speciálisan kiképzett védelmi személyzet nélkül, amelyre számos nemzetközi példát is találunk. ${ }^{18}$

Mechanikai védelem során a biztonsági szolgálat tagjainak ismerniük kell a kültéri védelmi elemek, emellett az építményvédelem részeit és a tárgyvédelem mechanikai elemeit. Tudniuk kell, hogy az adott objektum esetén mi a szerepük a komplex védelmi rendszerben, meghibásodásuk milyen veszéllyel jár, ezért például a járőrtevékenység ellenőrzése során az állapotuk ellenőrzésére figyelmet kell fordítani. ${ }^{19}$

\section{Rendkívüli események kezelése modul}

A rendkívüli események, katasztrófák legjellemzőbb eleme, hogy előre nem, vagy csak nehezen érzékelhetők, jelezhetők. Időbeni lefolyásuk, mértékük, bekövetkezési helyük és hatásuk becslése rendkívül nehéz feladat. ${ }^{20}$ Ennek ellenére felkészülést igényel a biztonsági szolgálattól és természetesen az objektumban tartózkodó emberektől is a rájuk háruló feladatok függvényében, hogy értékes időt nyerhessünk a felismerésben és az intézkedésre fordított folyamatban. ${ }^{21}$

Ennek keretében a vagyonőröknek tisztában kell lenniük az események főbb fajtáival, azok keletkezési helyével és kihatásával, az egyes típusokhoz köthető feladatokkal. Alkalmazniuk kell az intézkedéshez köthető ismereteket búncselekmény, szabálysértés esetén, a tűzjelzés, a segítségnyújtás során. Tudni kell az elsősegélynyújtás során az egyes sérülésekkel kapcsolatos fôbb feladatokat, a segitségkérés során várhatóan bekért információkat.

Ennek hatására a hirtelen, előre nem vagy csak nehezen megbecsülhető eseményeket, illetve azok láncolatának elemeit hamarabb, magabiztosan felismerik, rendszerbe állítják, helyes döntést hoznak és megteszik a szükséges ellenlépéseket. Ennek megvalósíthatósága érdekében kapott helyet a fejlesztési terv jelen moduljában az intézkedéstaktika és a kriminalisztika.

Az intézkedéstaktika jogszabályokban, belső normákban meghatározott jogok és kötelességek végrehajtásának módját, módszereit mutatja be, amelynek meg kell felelnie a jogszerűség, szakszerǔség, biztonság, arányosság, objektivitás és eredményesség elvének. Az őrszolgálat tagjainak ismerniük kell az intézkedést befolyásoló objektív és szubjektív tényezőket, körülményeket, a szolgálati és támadáselhárító

\footnotetext{
Tóth Attila: Az élőerő munkáját segítő technikai megoldások. Hadmérnök 13. (2018), 2. 29-36.

8 Tom Davenport - Steven Mark Miller: The future of work now: The multi-faceted mall security guard at a multi-faceted Jewel. Forbes, 2020. 09. 28.

19 Berek Lajos: Biztonságtechnika. Budapest, Nemzeti Közszolgálati Egyetem, 2014. 11-14.

Ürmösi Károly: A biztonság, a biztonság fogalma. Hadtudományi Szemle, 6. (2013), 4. 147-154.

21 Nassim Nicholas Taleb: A fekete hattyú avagy a legváratlanabb hatás. Budapest, Gondolat, 2007. 79.
} 
eszközökre vonatkozó követelményeket, alkalmazási taktikákat, az intézkedések gyakorlati végrehajtásának alapvető taktikáit. ${ }^{22}$

Bár a személy- és vagyonőri feladatellátás során nem szükséges a teljes körű kriminalisztikai felkészültség, a hatósági munkavégzés támogatása érdekében a vagyonőrnek ismernie kell a helyszínbiztosítás feladatait, a tárgyi eszközök sértetlenségét biztosító eljárást, a személy-, tárgy- és helyszínleírás jellemzőit, egy adott esemény dokumentálásának folyamatát. Emellett szükséges ismerniük az adatgyưjtési módszereket, a helyszínbiztosítás, a helyszíni szemle, a kihallgatási fogások jellemzőit, az elfogásra és a hatósági tanúkra vonatkozó taktikai ajánlásokat a munkakörük szakszerű ellátásának mértékében. Emellett viktimológiával is érdemes foglalkozni, hiszen az őrszolgálat tagjai is válhatnak a büncselekmények célpontjaivá, akadályokká, olyan személyekké, akik tudatosan vagy gondatlanul elősegítik egy bűncselekmény elkövetését. ${ }^{23}$

\section{Információbiztonsági modul}

Az információbiztonsági modul keretében szót ejtünk a biztonságtudatosságról, a feladatok ellátásához szükséges alapvető számítástechnikai tudásról, az információbiztonsági feladatokról, a „social engineering” veszélyeiről és az adatvédelmi szabályokról egy-egy tantárgy keretében.

A biztonságtudat fejlesztésének komoly szerepe van a fenyegetések és veszélyek felmérésében, elhárításában, a biztonság érzékelésében. ${ }^{24}$ Olyan kompetenciával kell az őrszolgálat egyes tagjainak rendelkezni, amely a biztonságot fenyegető helyzetek megoldásában hatékony és eredményes cselekvést tesz lehetővé. Ennek része a szakmai ismeretek alkalmazásán túl a digitális kompetencia fejlesztése is, ami a digitális eszközök biztonságos használatának elsajátításában nyújt segítséget, az alapvető felhasználáson túl adatvédelmi és információbiztonsági feladatokkal kiegészítve. ${ }^{25}$

\section{Kommunikáció modul}

A kommunikáció modul alá a pszichológia, a kommunikáció, az illemtan és az angol nyelv tantárgyak kerültek.

A biztonsági szolgálat tagjainak a feladatuk ellátásához és az intézkedések végrehajtásához a verbális és a nonverbális kommunikációs formát jól kell ismerni,

22 Krauzer Ernő: Intézkedéstaktika Személy- és vagyonőrök, valamint Fegyveres biztonsági örök részére. PRO-SEC Kft., 2012. 35-37.

23 Kaló József et al.: Személy- és vagyonvédelem. Budapest, Őrtanoda, 2013. 59-60.

24 Jávor Endre: Fésületlen gondolatok a biztonságról. Nemzetbiztonsági Szemle, 2. (2014), 3. 61-87.

25 Nyikes Zoltán: A biztonságtudatosság a digitális kompetencia tükrében. In XXI. Fiatal Műszakiak Tudományos Ülésszaka. Kolozsvár, 2016. 03. 17. 313-316. 
és a lehetőségekhez mérten tudatosan alkalmazni. A kommunikációt a vagyonőrnek kell irányítania, aminek a szakmai felkészültségen alapulva egyértelműnek, határozottnak, hitelesnek és egyben udvariasnak kell lennie. A verbális és metakommunikációnak összhangban kell lennie, ugyanakkor a másik fél verbális és nonverbális kommunikációját folyamatosan figyelnie és értékelnie kell, amelyekből következtetéseket kell levonnia. Szlengtől, szakzsargontól mentesen, tömören, célratörően kell az információkat átadni. ${ }^{26}$

Rendkívüli események kezelése során az őrszolgálatnak tudni kell a kríziskommunikáció előírásait alkalmazni. Tudni kell, hogy kinek mit, mikor és hogyan, milyen feltételek teljesülése esetén mondhat, azaz a beszédakkomodációt is figyelembe kell venni. ${ }^{27}$

A mindennapi feladatellátás során tisztelettel és az elvárható illemszabályok alkalmazásával kell együttmúködésre törekvően kommunikálni mind a megbízó munkavállalóival, mind a vendégeikkel, ügyfeleikkel, szerződéses vállalkozóival, de egymással is, az őrszolgálat tagjaival. Amennyiben ez akadályokba ütközik, úgy fel kell tudni ismerni ennek okait és tudatosan kell a helyzethez megfelelő megoldást találni.

A biztonsági szolgálat kommunikációjának speciális esete, amikor a fent említett ismeretek alkalmazására idegen nyelven kerül sor. Ebben nyújt segítséget a MOP rendszere.

A MOP rövidítés egy szaknyelvi képzési módszer angol nyelvű elnevezésének - mission-oriented preparation - betűszava, a magyar nyelvben a feladatorientált felkészítés elnevezést vezették be. ${ }^{28}$

A feladatorientált felkészítés módszerének kidolgozását, tantervi bevezetését és gyakorlati alkalmazását szükségessé tette az az igény, hogy az angol biztonságtechnikai szaknyelv oktatása önálló tantárgy keretében valósuljon meg abban a felsőoktatási intézményben, ahol a leendő szakemberek oktatása zajlik. A MOP magában foglalja egy adott szakma magas szintű képviselőivel és oktatóival kooperációban megvalósított szükségletelemzést, a korszerủ tananyagfejlesztést, az innovatív oktatási-képzési módszerek változatos és célhoz kötött alkalmazását, valamint visszacsatolások révén a MOP tartalmának és eljárásainak folyamatos fejlesztését. A MOP-képzés biztonságtechnikai szaknyelvi konstruktuma igen változatos. A tematikába beemelték olyan szakmai tantárgyak tartalmi elemeit, amelyek a képző intézmény curriculumának fontos részét alkotják, mint például kibervédelem, biometrikus azonosítás, vagy egyebek mellett a túzvédelem.

26 Krauzer (2012): i. m. 35-37; Devecsai János et al.: Bevezetés a biztonsági ốr és a testốr szakmába. Budapest, AzA Stúdió, 2003. 241-246.

27 Ürmösné Simon Gabriella: Érák, szubkultúrák, szocializáció, férfi-kontra női agy a gendernyelvészet tükrében. $M a-$ gyar Rendészet, 15. (2015), 2. 151-161; Gabriella Ürmösné Simon: A case study based on a spontaneous discourse of Greek-Hungarian bilinguals in respect of interjections, swear words and syntactical mistakes, as regards gender. Magyar Rendészet, 17. (2017), 4. 193-210.

28 Kovács Éva: The experiences of running advanced technical courses for engineering students at Bonát Bánki Faculty of Mechanical and Safety Engineering, Óbuda University. Biztonságtudományi Szemle, 3. (2021), 1. 65-78. 
A MOP jellegzetessége, hogy az oktatás kezdetén meghatározza azt a kívánatos, egy bővített mondatban megfogalmazható célt, amelyet az oktatás végére a hallgató el kell, hogy érjen. Ez lehet egy adott biztonsági területen való nagyobb célnyelvi jártasság elérése, vagy egy álláshoz, pozíció betöltéséhez vagy munkavégzéshez nélkülözhetetlen szaknyelvi ismeret elsajátítása, vagy akár oklevéllel igazolt szakmai nyelvvizsga letétele. Az oktatás befejezésekor a hallgató a kooperációban részt vevőkkel együttesen értékeli az oktatási cél megvalósulását, a program teljesítésének mikéntjét. Ebből az is adódik, hogy a MOP rugalmas a módszerek kiválasztásában, a szaknyelvi szegmens oktatásában, a hozzárendelhető tananyag megalkotásában annak tartalmára, mennyiségére és nyelvi szintjére való tekintettel is. A MOP megvalósításának konstans és elengedhetetlen követelménye azonban az említett kooperáció, különös tekintettel a szükségletelemzésre, amely kvalitatív megközelítésű módszerekkel, esettanulmányokkal, mélyanalízissel, a szaknyelvet célnyelven használók bevonásával zajlik. ${ }^{29}$ Ezen az elven alapulnak azok az egyéb modern megközelítések és oktatási módszerek, amelyek a tartalom-előállítást és bizonyos mértékben az alkalmazott oktatási metodikákat is alárendelik a konkrét és jól körülhatárolható nyelvi szükségleteknek. A képzés autentikusságát ugyanis a szakmai háttértudás, valamint a nyelvtudás közötti folyamatos interakció biztosítja. ${ }^{30}$

Az Internal Development Plan for Security Guards és a Mission-Oriented Preparation programok és az abban részt vevő oktatók, szakmai vezetők és a képzésben részesülő személy- és vagyonőrök jövőbeli együttműködése adja alapját az oktatás hasznosságának és hitelességének. A szaknyelvi kommunikációs modul kidolgozása az objektumspecifikus képzés moduljainak vállalati szinten elkezdett oktatása előtt hónapokkal megkezdődik. A tematika első hét, fentebb felsorolt alegységeihez tartozó általános angol nyelvi tananyagfejlesztés folyamatosan zajlik. Tekintettel a személyés vagyonőrök formális szakmai képzésének bemeneti, valamint kimeneti követelményeire, amelyeket nem kötnek nyelvi ismeretek meglétéhez, illetve vizsgakötelezettséghez, a tananyag nyelvi szintjének beállítását nem lehet előzetesen meglévő angol nyelvismerethez fúzni. A szaknyelvi anyag arra törekszik, hogy az IDPS jogi ismeretek, a munkavédelem, tűzvédelem, környezetvédelem, őrzés-védelem, biztonságtechnika, információbiztonság, rendkívüli események és objektumspecifikus ismeretek moduljainak angol nyelvi szókészletét, szaklexémáit a lehető legnagyobb változatosság megtartásával beemelje, miközben a lehető legkevesebb nyelvtanistrukturális alapok felhasználását kívánja meg. Ez a nyelvi szint egyidejúleg teszi lehetővé, hogy az angol nyelvvel kezdő szinten (A1 szint) ismerkedők, valamint az alapfokú (B1 szint) nyelvtudással rendelkezők is profitáljanak a célnyelvi kommunikációs modul elsajátításából. A bemeneti szint meghatározását előzetes gyor-

29 Borszéki Judit: Az English for Border and Coast Guards című nemzetközi szaknyelvi oktatóanyag fejlesztésének folyamata - a nem-nyelvész szakemberek szerepe. Porta Lingua, (2020), 231-247.

30 Havril Ágnes: A szaknyelvtudás konstruktumának modellezése. In Horváthné Molnár Katalin: Az alkalmazott nyelvészet regionális és globális szerepe. XXI. Magyar Alkalmazott Nyelvészeti Kongresszus, Szombathely, 2011. augusztus 29-31. 2012. 351-357. 
steszt, az úgynevezett „placement test”, szintfelmérő írásbeli teszt és/vagy rövid szóbeli elbeszélgetés segítheti. A tananyag nyelvtani-strukturális igényét az objektumban célnyelven előforduló szituatív produktumok is előírják. Az angol nyelvi források, szakmai-képzési anyagok, használati útmutatók, valós szakmai célnyelvi szituációk ${ }^{31}$ tanulmányozása után azonban általánosságban leszűrhető, melyek azok a nyelvtani ismeretek, amelyek a kidolgozott tananyagban szerepelhetnek, s ezek a következők:

- mondatrészek sorrendje (szórend, word order);

- egyszerú jelen idő (present simple);

- felszólítás (imperative);

- néhány módbeli segédige (modal auxiliaries);

- passzív szerkezet (passive voice).

A személy- és vagyonőrök angol szaknyelve a terület szakirodalmában használatos fogalom, az EVP vagy EOP, azaz english for vocational purposes vagy english for occupational purposes kategóriáját gazdagítja, ezáltal nem csupán strukturális, hanem szövegalkotói-funkcionális, valamint szociolingvisztikai jellemzőkkel is rendelkezik. A teljesség igénye nélkül, ám a tananyag tartalmi elemeire is rávilágít az előbbiek közül néhány:

- jelentéskészítés;

- esetleírás;

- normál ügymeneti és vészhelyzeti szóbeli kommunikáció;

- tömegek előtti bejelentés;

- hangosbemondás;

- telefonos interakció.

A szociolingvisztikai aspektus egyik legfőbb érdekessége, hogy a célnyelven megnyilvánuló szóbeli vagy írásbeli kommunikáció szinte minden esetben egy hierarchikus viszonyt feltételezve, abba illeszkedően történik, például munkahelyi vezető-beosztott munkatárs, vagyonőr-ügyfél, intézkedő hatóság-járőr alá-fölé rendeltségi kapcsolatában. Ennek az aspektusnak kell megfelelnie az alkalmazott udvariassági formuláknak, a kötelezően használandó megszólításoknak stb.

A MOP alkalmazása a személy- és vagyonőrök objektumspecifikus képzésében is megkívánja, hogy az adott vállalatra, épületre és munkakörre jellemző tartalmicélnyelvhasználati specifikumokat begyưjtse és tananyagába beépítse. Így kerül sor a szakmai és vállalati vezetőkkel egyeztetett és jóváhagyott tanmenet és tananyag összeállítására a kommunikációs modulon belül is. Jellemző témák lehetnek többek között a járőrellenőrző rendszerek, beléptető rendszerek működésével kapcsolatos párbeszédek, a külföldi vendégekkel vagy védett személyekkel megvalósuló kommunikáció, a tűzvédelemhez, tűzriasztáshoz kapcsolódó felszólítások

31 John F. Lemon: Private Security Officer basic training program. 2018. 
készségszintű ismerete, bombafenyegetéses telefonhívások azonnali, szakmai protokoll szerinti idegen nyelven történő kezelése. A tananyag összeállításakor figyelemmel kell lenni a szakmát gyakorlók mindennapi kommunikációjára, amelyet engedélyekhez kötött és bizalmasan kezelt korpuszgyújtéssel, jegyzeteléssel, esetlegesen felvételek készítésével és tananyaggá konvertálásával lehet autentikussá tenni. E tartalmi elemek együtteséből áll össze az objektum- és munkakörspecifikus angol célnyelvi, B1-es tudásszintű tananyag, amelynek elsajátítása szolgálja a személy- és vagyonőrök objektumspecifikus, naprakész képzettségét.

\section{Összefoglalás}

A személy- és vagyonőri tevékenység ellátásához szükséges szakképesítés megszerzését követőn is szükséges az ismeretek rendszeres karbantartása és ellenőrzése. Erre az igényre válaszul készült el Szabó Anikó által az IDPS, a Személy- és vagyonőrök Objektumspecifikus Fejlesztési Terve, amely modulrendszerű felépítésével bemutatja az egyes tantárgyakat modulonkénti besorolásban, megadja mindazon keretrendszert alkotó alapinformációkat, például a képzés időszakát, kivitelezhetőségi normáit, tervezett létszámot, amelynek segítségével az objektum biztonságáért felelős vezető vagy megbízottja összeállíthatja a képzési tervét a védett objektum jellemzőire specifikáltan. Emellett a képzési terv kommunikációs modulja integráltan tartalmazza a Kovács Éva által alkalmazott feladatorientált felkészítés (MOP) módszereit is, amelynek célja, hogy támogassa a személy- és vagyonőrök idegennyelvi szaknyelvi kommunikációját. Ennek érdekében a szerző bemutatja a folyamatos fejlesztési irányokat, például a tananyagfejlesztést, a rugalmas módszerek kiválasztását, vagy a szakmai kooperációt. A MOP szintfelmérő tesztje és rövid elbeszélgetési része emellett biztosítja, hogy a programban részt vevők kezdőként (A1 szint) vagy alapfokú (B1 szint) nyelvtudással rendelkezve is profitáljanak a célnyelvi kommunikációs modul elsajátításából.

Az IDPS-MOP képzési tervének gyakorlatba ültetése összeségében alapul szolgál a személy- és vagyonőrök egy adott munkakörben és feladatkörben végzett tevékenységi idejének növeléséhez, az adott cég pénzügyeinek optimalizálásához, a hosszú távú tervezhetőséghez, valamint a szakmára jellemző fluktuáció csökkentéséhez, ezáltal az általános biztonságérzet javításához. A személy- és vagyonbiztonság, a szélesebb értelemben vett közbiztonság megteremtése a hatóságok, a magánbiztonsági szektor szereplői, valamint az állampolgárok közös feladata. Jelen tanulmány szerzői az IDPS és MOP képzési tervek összeállításával, bevezetésével és múködtetésével járulnak ehhez hozzá. 


\section{FELHASZNÁLT IRODALOM}

10323009 számú Személy- és vagyonőr megnevezésü szakképesités megszerzésére irányuló szakmai képzéseket megalapozó programkövetelmény. Online: https://api.ikk.hu/storage/uploads/ files/10323009_szemely_es_vagyonor_pdf-1604054748107.pdf

Beregnyei József: Gyalogosok be/kiléptetése, ellenőrzése, csomagok átvizsgálása. Nemzeti Szakképzési és Felnőttképzési Intézet, é. n. Online: www.nive.hu/Downloads/Szakkepzesi_dokumentumok/ Bemeneti_kompetenciak_meresi_ertekelesi_eszkozrendszerenek_kialakitasa/19_0701_tartalomelem_008_munkaanyag_100531.pdf

Berek Lajos: Biztonságtechnika. Budapest, Nemzeti Közszolgálati Egyetem, 2014. Online: http://real. mtak.hu/19709/1/biztonsagtechnika.original.pdf

Berek Tamás - Bodrácska Gyula: Az élőerős őrzés az objektumvédelem építőipari ágazatában. Hadmérnök, 5. (2010), 4. 38-49. Online: www.hadmernok.hu/2010_4_berek_bodracska.pdf

Berek Tamás: ABV (CBRN) analitikai laboratórium beléptetőrendszere a biztonságos üzemeltetés szolgálatában. Hadmérnök, 6. (2011), 2. 21-36. Online: www.hadmernok.hu/2011_2_berek.pdf

Bodrácska Gyula: Vagyonvédelmi kockázatok az építőiparban különös tekintettel a lopások fajtáira, típusaira, anyagaira, segédanyagaira. Hadmérnök, 5. (2010), 1. 5-16. Online: https://docplayer. hu/5598998-Vagyonvedelmi-kockazatok-az-epitoiparban-kulonos-tekintettel-a-lopasok-fajtaira-tipusaira-anyagaira-seged-anyagaira.html

Borszéki Judit: Az English for Border and Coast Guards című nemzetközi szaknyelvi oktatóanyag fejlesztésének folyamata - a nem-nyelvész szakemberek szerepe. Porta Lingua, (2020), 231-247. Online: https://doi.org/10.48040/PL.2020.19

Davenport, Tom - Steven Mark Miller: The future of work now: The multi-faceted mall security guard at a multi-faceted Jewel. Forbes, 2020. 09. 28. Online: https://ink.library.smu.edu.sg/sis_research/5297/

Devecsai János - Hangyasi Sándor - Kapor Gábor et al.: Bevezetés a biztonsági ör és a testốr szakmába. Budapest, AzA Stúdió, 2003.

Guttengeber Ádám: Személy- és vagyonörök, biztonságtechnikai szakemberek tankönyve. Budapest, Pro-Sec Kft., 2000.

Havril Ágnes: A szaknyelvtudás konstruktumának modellezése. In Horváthné Molnár Katalin: Az alkalmazott nyelvészet regionális és globális szerepe. XXI. Magyar Alkalmazott Nyelvészeti Kongresszus, Szombathely, 2011. augusztus 29-31. 2012. 351-357. Online: https://docplayer. hu/36865937-A-szaknyelvtudas-konstruktumanak-modellezese-havril-agnes.html

Jávor Endre: Fésületlen gondolatok a biztonságról. Nemzetbiztonsági Szemle, 2. (2014), 3. 61-87. Online: https://folyoirat.ludovika.hu/index.php/nbsz/article/view/2085/1363

Kaló József - Buzás Gábor - Simon Attila - Takács Péter: Személy-és vagyonvédelem. Őrtanoda, 2013.

Kitteringham, Glen: Guard training programs: A development guide. Security Management, (2020), 7. Online: www.asisonline.org/security-management-magazine/articles/2020/07/guard-training-programs-a-development-guide/

Kovács Éva - Christián László: Private security and municipal policing in academic education - an international overview. Magyar Rendészet, (2018), 4. 49-59. Online: https://doi.org/10.32577/ mr.2018.4.3

Kovács Éva: The experiences of running advanced technical courses for engineering students at Bonát Bánki Faculty of Mechanical and Safety Engineering, Óbuda University. Biztonságtudományi Szemle, 3. (2021), 1. 65-78.

Krauzer Ernö: Intézkedéstaktika Személy- és vagyonörök, valamint Fegyveres biztonsági örök részére. PRO-SEC Kft., 2012.

Lasz György: A legjobb gyakorlat: Fejlesztés és fejlődés. Hadmérnök, 6. (2011), 1. 59-72.

Lemon, John F.: Private Security Officer basic training program. 2018. Online: www.academia. edu/37093826/Private_Security_Officer_Basic_Training_Manual 
Nyikes Zoltán: A biztonságtudatosság a digitális kompetencia tükrében. In XXI. Fiatal Müszakiak Tudományos Ülésszaka, Kolozsvár, 2016. 03. 17. 313-316. Online: https://doi.org/10.33895/mtk2016.05.69

Rendőrség: A rendőri hivatás etikai kódexe. é. n. Online: www.police.hu/a-rendorsegrol/testulet/altalanosan/a-rendori-hivatas-etikai-kodexe

Sik Gotthilf: A szolgálatra történő felkészülés, valamint a szolgálat átadása, átvétele, ennek jelentése. Nemzeti Szakképzési és Felnőttképzési Intézet, é. n. Online: www.nive.hu/Downloads/Szakkepzesi_dokumentumok/Bemeneti_kompetenciak_meresi_ertekelesi_eszkozrendszerenek_kialakitasa/19_0701_001_101030.pdf

Sik Gotthilf: A védett objektumon belüli járörszolgálat ellátása alapesetben. Nemzeti Szakképzési és Felnőttképzési Intézet, é. n. Online: www.nive.hu/Downloads/Szakkepzesi_dokumentumok/Bemeneti_kompetenciak_meresi_ertekelesi_eszkozrendszerenek_kialakitasa/19_0701_002_101030.pdf.

Szabó Anikó: A szabályzatok szerepe az objektumok őrzésvédelmében. Müszaki Katonai Közlöny, 27. (2017), 1. 2-15. Online: https://folyoirat.ludovika.hu/index.php/mkk/article/ view/2090/1369

Szabó, Anikó - Zoltán Rajnai: The review of the external risk factors during the operation training plan of the security guards. IEEE 15th International Symposium on Intelligent Systems and Informatics (SISY). Szabadka, 2017. Online: https://doi.org/10.1109/SISY.2017.8080583

Személy-, Vagyonvédelmi és Magánnyomozói Szakmai Kamara: Etikai szabályzat. 2016. Online: www.szakmaikamara.hu/files/Etikai_szabalyzat_2016-01-15.pdf

Taleb, Nassim Nicholas: A fekete hattyú avagy a legváratlanabb hatás. Budapest, Gondolat, 2007.

Tóth Attila: Az élőerő munkáját segítő technikai megoldások. Hadmérnök, 13. (2018), 2. 29-36. Online: http://hadmernok.hu/182_03_toth.pdf

Ürmösi Károly: A biztonság, a biztonság fogalma. Hadtudományi Szemle, 6. (2013), 4. 147-154. Online: http://m.ludita.uni-nke.hu/repozitorium/bitstream/handle/11410/1189/2013_4_alt_urmosi.pdf?sequence $=1$ \&isAllowed $=y$

Ürmösné Simon Gabriella: A case study based on a spontaneous discourse of Greek-Hungarian bilinguals in respect of interjections, swear words and syntactical mistakes, as regards gender. Magyar Rendészet, 17. (2017), 4. 193-210. Online: https://folyoirat.ludovika.hu/index.php/magyrend/article/view/1874/1163

Ürmösné Simon Gabriella: Érák, szubkultúrák, szocializáció, férfi-kontra női agy a gendernyelvészet tükrében. Magyar Rendészet, 15. (2015), 2. 151-161. Online: http://real.mtak.hu/107822/1/ Erak_szubkulturak_szocializacio_ferfi-kontranoiagyagendernyelveszettukreben_MagyarRendeszet20152NKESzolgaltatoKFT_Budapest_2015_.pdf

Váradi Julianna: Általános és speciális jogszabályi elöirások, és etikai szabályok. Személy-és vagyonvédelmi alapfeladatok. Nemzeti Szakképzési és Felnőttképzési Intézet, é. n. Online: www.nive.hu/Downloads/Szakkepzesi_dokumentumok/Bemeneti_kompetenciak_meresi_ertekelesi_eszkozrendszerenek_kialakitasa/19_0701_005_101030.pdf

Váradi Julianna: Általános és speciális jogszabályi előirások, normák, valamint az etikai, titokvédelmi szabályok. Munkaanyag. Nemzeti Szakképzési és Felnőttképzési Intézet, é. n. Online: https:// docplayer.hu/16681722-Munkaanyag-varadi-julianna-altalanos-es-specialis-jogszabalyi-eloirasok-normak-valamint-az-etikai-titokvedelmi-szabalyok.html

Zsákai Róbert - Muhoray Árpád: A pszichés viselkedések szerepe a katasztrófahelyzetekben. Szakmai Szemle, (2014), 3. 214-223. Online: www.knbsz.gov.hu/hu/letoltes/szsz/2014_3_szam.pdf

\section{Jogi források}

2005. évi CXXXIII. törvény a személy- és vagyonvédelmi, valamint a magánnyomozói tevékenység szabályairól 
SZABÓ Anikó - KOVÁCS Éva: A személy- és vagyonőrök objektumspecifikus fejlesztési terve...

2012. évi CXX. törvény az egyes rendészeti feladatokat ellátó személyek tevékenységéről, valamint egyes törvényeknek az iskolakerülés elleni fellépést biztosító módosításáról

22/2006. (IV. 25.) BM rendelet a személy- és vagyonvédelmi, valamint a magánnyomozói tevékenység szabályairól szóló 2005. évi CXXXIII. törvény végrehajtásáról

68/2012. (XII. 14.) BM rendelet a rendészeti feladatokat ellátó személyek, a segédfelügyelők, valamint a személy- és vagyonőrök képzéséről és vizsgáztatásáról

\section{ABSTRACT \\ The Introduction of the Internal Development Plan for Security Guards Applied Jointly with Mission-Oriented Preparation}

Anikó SZABÓ - Éva KOVÁCS

The role of security guards and close protection bodyguards in the private security sector is inevitable in creating and maintaining a common sense of subjective security. Following the formal education of the security guards and bodyguards, it is necessary to continuously expand and upgrade their knowledge. This must focus on keeping up-to-date with the changes of the legal environment, technological novelties used in their course of duty, awareness and application of occupational health safety and fire protection equipment. However, employee turnover prevalent in this sector makes it difficult or even impossible to transfer the necessary knowledge pertaining to the nature of duty in particular facilities or sites. In response to this demand, the author of this article, Anikó Szabó has devised the 'Internal Development Plan for Security Guards' (IDPS), which offers a module-based, flexible solution to the representatives of the profession. Integrated into the communication module of this internal training plan is 'Mission-Oriented Preparation' (MOP), developed by co-author Éva Kovács.

Keywords: security guard, development plan, Mission-Oriented Preparation, private security, property protection, Security Technology English, IDPS 